\title{
Guest-Editor's Introduction
}

\section{Alon Goshen-Gottstein ${ }^{1}$}

Published online: 25 November 2021

(c) The Author(s), under exclusive licence to Springer Nature B.V. 2021

The present issue of Contemporary Jewry is devoted to Judaism and Hinduism and different dimensions of their encounter. It follows on the heels of issue 40, 1 of Contemporary Jewry, which I also had the honor of guest-editing, and which was devoted more broadly to the relations between Judaism and world religions. In fact, as that volume exceeded the recommended length for an issue of the journal, in consultation with Harriet Hartman, we decided to devote a special issue of the journal to one particular relationship, that of Judaism and Hinduism. This grows out of my own interest in the field, and specifically out of two monographs that I have published on the subject, and that are engaged in the present issue. For the benefit of those who did not see the earlier volume, it was centered around my (mostly) published work. Authors were asked to review a series of publications, authored or edited by me, that tackle the issue of Judaism and world religions. Following several sessions held in the framework of the seventeenth World Congress of Jewish Studies, devoted to Judaism and World Religions, in dialogue with my work, an invitation came from Harriet Hartman, editor of Contemporary Jewry, to feature these discussions in Contemporary Jewry.

With the passage of time, I am even more grateful to Harriet, not only for her invitation but for her patiently and supportively shepherding the project along, especially against the many technological annoyances that we encountered along the way.

The concept of the earlier special issue was to use each of the reviews that discussed one of my books as a launchpad for a broader discussion, in which some aspect of Judaism's relationship with other religions and how it plays out in contemporary social reality and present-day thought would be explored. The format was anomalous, and to a certain extent so was the work of the editor. The essays envisioned for the journal were not pure book reviews nor were they original research pieces. They were a cross between a review, a statement of contemporary thought, and an analysis of some aspect of present-day reality and the challenges it poses to Judaism. Two of the essays featured in the present issue of the journal grew out

Alon Goshen-Gottstein

gogo@elijah.org.il

1 The Elijah Interfaith Institute, Jerusalem, Israel 
of those conversations. Several others were added, in order to explore the theme of "Judaism and Hinduism" from additional perspectives.

The issue of recognition of another religion, its validation, and the ensuing possibilities for learning, receiving, and growing through the encounter with that religion are the focus of the twin volumes on Judaism and Hinduism, The Jewish Encounter with Hinduism: Wisdom, Spirituality, Identity and Same God, Other god: Judaism, Hinduism and the Problem of Idolatry. ${ }^{1}$ Almost all the theoretical challenges and possibilities that arise in the context of a Jewish view of and encounter with another religion come to expression in the study of the Jewish encounter with and a possible Jewish view of Hinduism. The challenge of legitimation occurs at the most fundamental level - is it a legitimate religion, or does it constitute avoda zarah, idolatry? The possibilities for mutual growth and inspiration are studied through the many angles of the contemporary and unprecedented encounter where a massive number of young Israelis follow in the footsteps of American and European Jewish youth decades earlier in exploring the spiritual riches of India. Once again, we encounter the two poles of identity and spirituality. Jewish identity is threatened by encounter with another religion at the same time as new spiritual openings arise. These come to light for practitioners, but even more significantly for Jewish thought and Jewish tradition, as it encounters a new and significant conversation partner, in the form of Hindu thought. In the same way that Judaism has grown throughout the centuries in its encounter with other traditions and civilizations, so too this new religious encounter opens up multiple possibilities for revisiting many lost parts of Jewish tradition and gaining fresh perspectives on fundamentals of a religious view of reality and of Judaism's position in relation to world religions.

My work in these two books is not purely descriptive. It is part of a constructive approach to how Judaism and world religions should be viewed in the contemporary global context, the spiritual challenges this presents, and the educational, halachic, and theological moves that can, or should, be made, in relating to Hinduism, and more broadly to other religions. For this reason, the two essays that dialogue with my work similarly take positions and make constructive suggestions concerning Judaism's relation with Hinduism. Alan Unterman's response to The Jewish Encounter with Hinduism and Marc Shapiro's response to Same God, Other god are testimony to the vitality of the issues under discussion and to the options that tradition places before the contemporary thinker and how these individuals go about making them. Needless to say, the respondents do not agree in all matters with the positions I myself have suggested. But, as a reading of my work actually reveals, my project is less about adopting a particular stance than it is about advancing an informed and nuanced discussion. In this sense, both responses make important contributions to an ongoing conversation.

As the volume is devoted to Judaism and Hinduism, it opens with an overview of their relationship, in historical and philosophical/halachic terms. The essay is written in encyclopedic form and offers a summary of many of the themes expounded in greater detail in The Jewish Encounter with Hinduism. Revising this essay, written

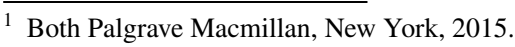


less than a decade ago, first for publication and then following helpful comments offered by a reviewer, was an eye-opener in and of itself. It showed how fast-moving this domain of study and engagement is. Within a short span of time, formative events took place, specific challenges arose, new publications appeared, and the field advanced. The exercise of updating this essay so soon after it had been first penned is, for me, one more sign of the vitality and dynamism of Jewish-Hindu relations and why they deserve ongoing attention.

It is likely the case that all those who engage in this area of study do so, to some degree or another, as part of their own personal (spiritual) journey, and certainly to some extent away from the comfort of their study. My introduction to both books spells out my own personal journey. Respondents to my work were chosen because of their known interest in the field, which exceeds a purely academic interest. One author, in particular, offers an overview and reflection on his own academic journey and how it involved both areas of study. Paul Morris' essay reviews his academic journey through various philosophical standpoints from which Judaism is appreciated, in relation to Hinduism. It makes us realize that the study of Hinduism and the study of Judaism are as much part of the present encounter of the different faiths as are more religiously oriented meetings of religious leaders and spiritual seekers. This should be appreciated in relation to the essay that concludes the special issue, that of Francis Clooney S.J. Clooney is a Jesuit priest and one of the founders of the contemporary academic discipline of comparative theology. He has spent decades studying Hinduism, in the context of a comparative theology, carried out in relation to Christianity. Given the concerns of this issue, I asked Clooney to share some of the lessons of his own journey and what benefit they may bring to students of Judaism and Hinduism. I believe this is the first time such an exercise is attempted by anyone.

If there is any message or conclusion to be drawn from this issue, it is that we are engaged in a long-term project. We must therefore be well equipped to undertake it and invest ourselves in further advancing it. Being well equipped is a matter of knowledge, open mindedness, and a willingness to learn the lessons learned by members of other traditions. To all these, our special issue contributes. As to the future advancement of the field, I conclude with an expression of hope that this volume will advance interest and provide further inspiration for a study that, as the essays in this collection reveal, is never narrowly academic and is always rich in meaning.

Publisher's Note Springer Nature remains neutral with regard to jurisdictional claims in published maps and institutional affiliations.

Alon Goshen-Gottstein is the founder and director of the Elijah Interfaith Institute in Jerusalem, Israel. He is acknowledged as one of the world's leading figures in interreligious dialogue, specializing in bridging the theological and academic dimension with a variety of practical initiatives, especially involving world religious leadership. He is the author or editor of over 20 volumes on comparative religion, including The Jewish Encounter with Hinduism: Wisdom, Spirituality, Identity and Same God, Other god: Judaism, Hinduism, and the Problem of Idolatry, both addressed in this special issue. 